\section{Highest inhabitants in the world}

SIR-In 1935, members of the International High Altitude Expedition went to the Aucanquilcha sulphur mine in north Chile $\left(21^{\circ} 12^{\prime} \mathrm{S}, 68^{\circ} 28^{\prime} \mathrm{W}\right)$ to study their own physiological adaptations to extreme altitude, and also to make some measurements on the local residents ${ }^{1}$. They described a group of miners who worked at the mine, which was said to be at an altitude of $5,800 \mathrm{~m}$, but lived at an altitude of 4,340 $\mathrm{m}$, preferring to climb $500 \mathrm{~m}$ on foot every day, which took about an hour and a half, rather than live at the extreme altitude of the mine.

The fact that the miners did not live at the mine itself has often been cited as evidence that people cannot live that high. Furthermore when eight physiologists on the Himalayan Scientific and Mountaineering Expedition of 1960-1961, under the scientific leadership of L.G.C.E. Pugh, spent up to 100 days in a prefabricated hut at an altitude of $5,800 \mathrm{~m}$ where the barometric pressure averaged about 380 torr, they seemed to confirm the view. In spite of reasonably good living conditions, ample food, and a healthy exercise programme, they steadily lost weight at the rate of $0.5-1.5 \mathrm{~kg}$ per week ${ }^{2}$.

It is remarkable that although the Aucanquilcha miners have often been cited as the highest inhabitants of the world ${ }^{3.4}$, and therefore are of considerable scientific interest, there is no report of them being visited by physiologists since 1935 . Last year, however, I had the opportunity to visit the mine with the Chilean physiologist, Raimundo Santolaya, and was astonished to find that four caretakers were living at the mine itself in a galva-

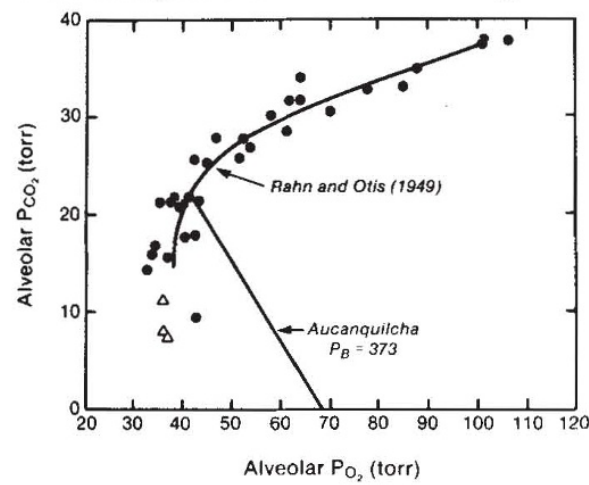

Oxygen-carbon dioxide diagram showing alveolar gas composition of both permanent residents and lowlanders acclimatized to high altitude. Most of the data were collated by Rahn and Otis ${ }^{6}$. The three triangles bottom left were obtained at extreme altitudes on Mount Everest? Diagonal line shows respiratory exchange ratio of 0.85 for barometric pressure of 372 torr and predicts that the inhabitants at $5,950 \mathrm{~m}$ will have alveolar $P_{\mathrm{O}_{2}}$ and $P_{\mathrm{CO}_{2}}$ values of approximately 42 and 22 torr, respectively. nized iron hut. One man had been living there for two years when I met him, but most of the caretakers live there for shorter periods and they all descend by truck to Amincha $(4,200 \mathrm{~m})$ on Sundays to play football. Conversations with the manager of the mine made it clear that only a small subset of miners are able to tolerate the altitude. Nevertheless it is clear that some people can live at this altitude for indefinite periods of time. The miners are mostly Bolivian natives who normally reside between 2,000 and $4,000 \mathrm{~m}$.

Although the 1935 expedition put the mine at $5,800 \mathrm{~m}$, a 1972 large-scale contour map of the area (Institute of Military Geography, Santiago) puts it at $5,950 \mathrm{~m}$. We measured the barometric pressure as 373 torr and a reading of 371 torr was made by R.B. Schoene in March 1986. The pressure-altitude relationship is latitude-dependent and the latitude of Aucanquilcha at $21^{\circ}$ south is similar to that ot Mount Everest ( $28^{\circ}$ north) where the relationship has been accurately measur$\mathrm{ed}^{5}$. This confirms an altitude of approximately $5,950 \mathrm{~m}$.

Few physiological data are yet available on these men. The barometric pressure of 371-373 torr means that the $P_{\mathrm{O}_{2}}$ of moist inspired gas is only 68 torr. If their alveolar $P_{\mathrm{O}_{2}}$ and $P_{\mathrm{CO}_{2}}$ conform to the pattern previously described for acclimatized lowlanders and high altitude residents ${ }^{6,7}$ they would have alveolar $P_{\mathrm{O}_{2}}$ and $P_{\mathrm{CO}_{2}}$ values of approximately 42 and 22 torr respectively (see figure). Arterial blood samples were taken from three of the men in March of this year when they were visiting Ollague (3,700 m $P_{\mathrm{B}} 490$ torr) and these gave a mean haematocrit of 60.89 per cent which is similar to that of acclimatized lowlanders at a similar altitude ${ }^{3}$.

Few people live permanently above $5,000 \mathrm{~m}$ even in the Peruvian Andes, or the Himalayan ranges of Nepal or Tibet. The caretakers of the Aucanquilcha mine apparently live at a far greater altitude than anyone else in the world.

I am indebted to R. Santolaya for making the arrangements to visit the mine, to R.M. Winslow for measuring the hematocrits and to R.B. Schoene for a measurement of barometric pressure. JOHN B. WEST

Department of Medicine,

University of California,

San Diego, La Jolla,

California 92093, USA

Keys, A. Sci. Montly 43, 280-312 (1936)

2. Pugh, L.G.C.E. Brit. med. J. 2, 621-627 (1962)

. Ward, M. In Mountain Medicine (van Norstrand Reinhold, New York, 1975).

4. Heath, F. \& Williams, D.R. in Man at High Altitude (Churchill Livingstone, London, 1977).

5est, J.B., Lahiri, S., Maret, K.H., Peters, R.M. \& Pizzo. C.J. J. appl. Physiol. 54, 1188-1194 (1983).

6. Rahn, H. \& Otis, A. B. Am. J. Physiol. 157, 445-462 (1949)

7. West, J.B. et al. J. appl. Physiol. 55, 678-687 (1983).

\section{Functions of leaf fall}

SIR-Ford has suggested that leaf fall is the mechanism of excretion in vascular plants ${ }^{1}$. But to view the senescing leaf simply as an 'excretophore' may be to limit our vision. Some species may avoid accumulating high concentrations of heavy metals by removing them in senescent leaves ${ }^{2}$. The dead leaves of other species release allelopathic compounds which play an active part in interspecific competition $^{3}$. And the maintenance - indeed the creation - of the plant's habitat, the A and B soil horizons, depends on leaf fall. The degree to which nutrient elements are withdrawn from leaves before they fall varies between ecological communities and correlates with the availability of nutrients in the soil ${ }^{4}$. Thus elimination of waste products of metabolism may not be leaf fall's only adaptive function.

A contrary view ${ }^{5}$ is that higher plants have been able to derive a variety of selective advantages from their dead and dying parts, thanks to their 'modular' form of construction ${ }^{6}$. This allows parts of the organism to be shed without prejudicing the survival of the whole. The result is that as in life so in death and fall, leaves have been subject to many selection pressures and many functions are now achieved by the process.

The practical importance of all this is that it implies that leaf senescence is not simply an avoidable evil. The use of 'antisenescence' genes or chemicals to increase leaf area duration and therefore yield in agricultural crops, may prove to be not quite as straightforward as has sometimes? been assumed.

RICHARD C. HARDWICK

Institute of Horticultural Research, Wellesbourne, Warwick CV35 9EF, UK

1. Ford, B. J. Nature 323, 763 (1986).

2. Waughman, G. J. \& Bellamy, D. J. Ann. bot. 47, 141-145 (1981).

Sydes, C. \& Grime, J. P. J. Ecol. 69, 237-248 (1981)

4. Grubb, P. J. A. Rev. Ecol. Syst. 8, 83-107 (1977).

Hardwick, R. C. British Plant Growth Regulator Group Monogr. 9, 61-74 (1983).

6. Hardwick, R. C. Phil. Trans. R. Soc. B313, 161-173 (1986)

7. Abu-Shakra, S. S., Phillips, D. A. \& Huffaker, R. C. Science 199, 973-975 (1978).

\section{Undirectional spin}

SIR-When I wrote my paper on undirectional $\operatorname{spin}^{1}$, which was recently referred to in Nature ${ }^{2}$,I unhappily had not seen a paper $^{3}$ on this topic which preceded mine by a few years. This highly illuminating work, which overlaps mine hardly at all, is particularly to be recommended to your readers for its excellent simulations.

\section{Churchill College}

HERMANN BONDI

\section{Cambridge CB3 ODS, UK}

Bondi, H. Proc. R. Soc. A405, $265-274$ (1986)

Walgate, R. Nature 323, 204 (1986)

3. Kane, T.R. \& Levinson, D.A. Int. J. non-lin. Mech. 17, $175-186(1982)$ 